\title{
ПІДВИЩЕННЯ ЯКОСТІ ГАЗОЛАЗЕРНОЇ РІЗКИ МЕТАЛЕВИХ МАТЕРІАЛІВ ЗА РАХУНОК УСУНЕННЯ ГРАТУ НА КРОМКАХ РІЗІВ ПРИ ВИКОРИСТАНН В ПОЛІГРАФІЧНІЙ ПРОМИСЛОВОСТІ
}

( В. В. Романенко, к.т.н., доцент, НТУУ «КПІ», Київ, Україна

В данной работе на основе анализа процесса образования грата при газолазерной резке металлических материалов предложено оригинальное устройство для такой обработки для нужд полиграфической промышленности, которое обеспечивает получение высокого качества кромок получаемых резов в результате устранения гратообразования непосредственно в процессе резки.

In this work on the basis of analysis of process of formation of hardenings influxes (grat) at gas-assisted laser cutting of metallic materials an original device is offered for such treatment for the needs of polygraphy industry, which provides the receipt of high quality of cutting process as a result of removal of grat receipt directly in the process of cutting.

\section{Постановка проблеми}

Лазерна різка різноманітних металевих матеріалів з вуглецевих, неіржавіючих сталей та титанових сплавів товщиною від 1 до 20 мм з одночасною співвісною подачею допоміжного газового струменя в зону різки, широко вживана як в поліграфічній промисловості, так і в інших галузях сучасного виробництва, вимагає високої якості виконання кромок різу, щоб виключити потребу в подальшій їх обробці. Розглядаючи якість поверхні різів в різних металах, слід врахувати, що на нижніх кромках вирізаних деталей можливе утворення металевих напливів, званих гратом. Утворення грату відбувається в результаті змочування поверхні розігрітого твердого металу рідким металом і його окисла- ми, що видаляються з порожнини різу, за рахунок утворення хімічних сполук, твердих і рідких розчинів, дифузійних процесів в поверхневому шарі змочуваного твердого металу. Наявність грату значно знижує якість лазерної різки, а найчастіше і недопустимо. Тому дуже важливо в процесі обробки унеможливити гратоутворення для забезпечення необхідної якості і чистоти кромок матеріалу, що розрізається.

\section{Мета роботи}

Підвищення якості кромок деталей вирізуваних при газолазерній різці металевих матеріалів за рахунок усунення утворення грату на цих кромках безпосередньо в процесі різки для потреб поліграфічної промисловості. 


\section{Результати проведених досліджень}

Одним із шляхів боротьби 3 гратом є правильний підбір режимів обробки. При газолазерній різці вуглецевих сталей на режимах $з$ найбільшою продуктивністю, не дивлячись на отримувану якість різів, спостерігається значне утворення грату (рис. 1, а) [1]. При виборі ж режимів, необхідних для здобуття якісних різів, нижня кромка різу, зазвичай, вільна від грату (рис. 1, б). На відміну від вуглецевих при розрізанні неіржавіючих сталей i титанових сплавів грат утворюються при будь-яких режимах різки, проте при обробці на режимах, що дозволяють отримати високу якість, його утворюється менше.

Ефективним шляхом боротьби з гратом є підбір поверхневоактивних речовин, які запобігають змочуванню деталі їі рідкими окислами, не руйнуючись при цьому від дії високих температур. Проте попередне нанесення таких покриттів вимагає додаткових технологічних операцій i, крім того, не завжди буває допустимим і можливим. То-

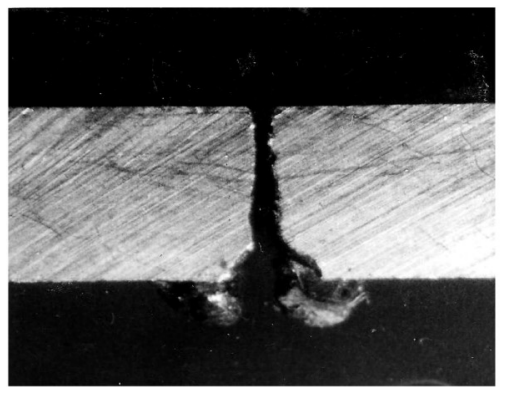

му найдоцільніше розробляти спеціальні методи, що дозволяють усувати утворення грату безпосередньо в процесі лазерної обробки.

Одним із можливих шляхів видалення грату 3 нижньої кромки деталі безпосередньо під час різки $є$ розміщення під заготовкою, що розрізається, співісно лазерному різаку, постійно притискуваного до заготовки кільцевого скребка, виконаного 3 тугоплавкого матеріалу [1]. Внутрішній діаметр скребка виконаний дещо більшим ширини отримуваного різу, що забезпечує безперешкодний вихід продуктів руйнування з порожнини різу. Рідкий метал, що з'являється в процесі різки на нижній кромці, не встигнувши охолонути і закресталізуватися, зчищається скребком. Круговий перетин скребка дозволяє виконувати вирізку складноконтурних деталей.

Відомі пристрої для лазерної різки, що використовують подачу в зону обробки (спільно з робочим газом) струменя хладоагента, наприклад, води [2, 3]. Рідина охолоджує рідкий метал і його окисли, що течуть по по-

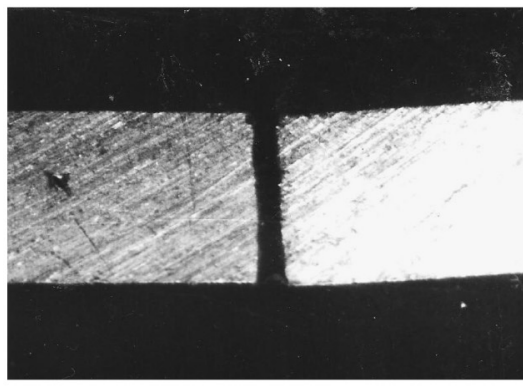

б

Рис. 1. Поперечний перетин різів, виконаних з утворенням грата на нижній кромці (а) і без гратоутворення (б) 
верхні руйнування, та сприяє їх коагуляції і частковому затвердінню. Це запобігає розтіканню металу по нижній кромці і, як підсумок, гратоутворенню.

Автором розроблений пристрій для усунення утворення грату безпосередньо в процесі різки, принцип роботи якого полягає в наступному (рис. 2) [4]. Пристрій для газолазерної різки матеріалів містить фокусуючу лінзу 1, що концентрує лазерне випромінювання 2 на верхній кромці заготовки 3, що розрізається. Остання встановлена на робочому столі 4. Спільно 3 лазерним випромінюванням і співісно йому в зону обробки піддуваєтся газовий струмінь, що формується соплом 5.
Співісно соплу 5 знизу заготовки на відстані $L=2 . .5$ мм від їі нижньої кромки встановлено спеціальний пристрій 6 (назвемо його «гратовідсікачем»), виконаний у вигляді сопла Лаваля з вхідним отвором діаметром D на 3...5 мм більшим ширини отримуваного різу b (див. рис. 2). Це забезпечує повне попадання в гратовідсікач струменя робочого газу і продуктів руйнування, що виходять 3 порожнини різу, незважаючи на наявне розширення газового потоку. Гратовідсікач 6 розміщується на вході системи 7 відведення продуктів руйнування, яка, як правило, забезпечена вакуумною системою 8. Для встановлення необхідної відстані L між нижньою частиною заготовки та

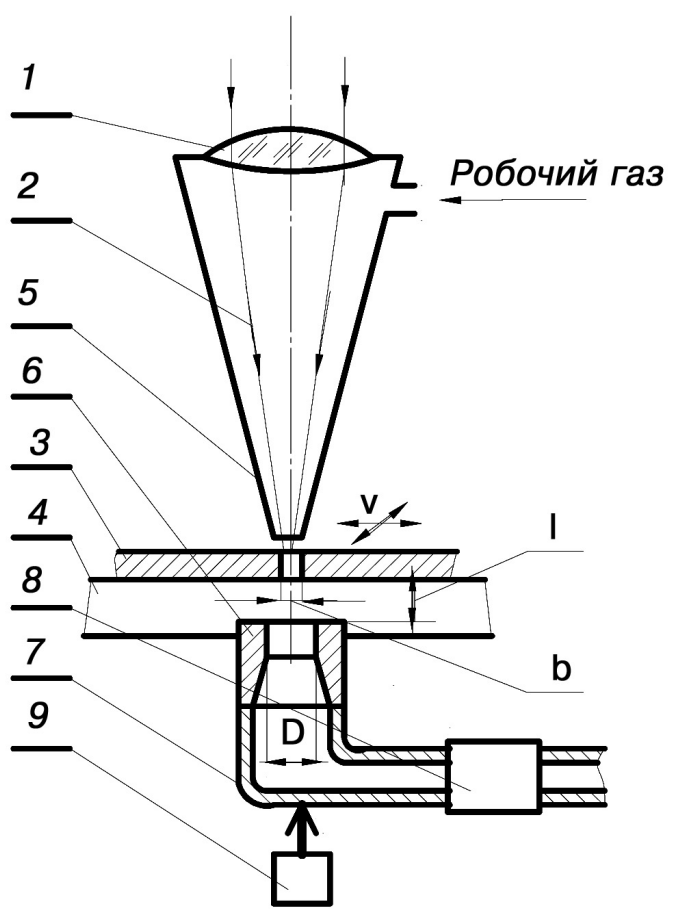

Рис. 2. Пристрій для усунення утворення грату при газолазерній різці металевих матеріалів безпосередньо в процесі різки 
гратовідсікачем в ручному або автоматичному режимі передбачений блок переміщення 9.

Даний пристрій працює слідуючим чином. Процес газолазерної різки здійснюється при фокусуванні лазерного випромінювання 2 лінзою 1 на поверхні заготовки 3, що розрізається, із спільною подачею в зону обробки співісного газового струменя з сопла 5. Відпрацьований газовий струмінь, що виходить із зони різки разом 3 продуктами руйнування, потрапляє у вхідний отвір D сопла Лаваля гратовідсікача 6, викликаючи (завдяки ежекторному ефекту) розрядження в зазорі між тильною стороною заготовки 3 і торцевою поверхнею гратовідсікача 6. Це розрядження протидіє наміру рідкого металу розпливатися по нижній кромці заготовки та забезпечує його втягування в область газового струменя (за принципом пульвілізатора) з подальшим його виносом разом з іншими продуктами руйнування через сопло Лаваля гратовідсікача 6 в систему відведення продуктів руйнування 7 і утилізацію. Величина створюваного ежекторного розрядження залежить від швидкості витікання газового струменя, а отже, від тиску піддуваємого через сопло 5 робочого газу та підсилюється із зростанням останнього.

Крім того, на величину розрядження впливає величина відстані L між заготовкою і гратовідсікачем та значення діаметру D вхідного отвору сопла Лаваля. Збільшення відстані L більше величини в 2...5 мм веде до різкого погіршення процесу гратовідсікання із-за зниження розрядження, тоді як зменшення $\mathrm{L}$ може привести до повного заповнення проміжку «заготовка-гратовідсікач» розплавленими продуктами руйнування i, як наслідок, до припинення процесу гратовідсікання. За допомогою блоку переміщення 9 гратовідсікач 6 розміщується на необхідній відстані від заготовки 3. Для здійснення ж автоматичного налаштування на відстань L гратовідсікач забезпечується датчиком положення, наприклад, ємкісного типу. У той же час збільшення D по відношенню до ширини отримуваного різу b більш, ніж на 3...5 мм, також веде до різкого погіршення гратовідсікання в результаті зниження ефекту ежекції, тоді як зменшення D викличе осадження частини продуктів руйнування на поверхні гратовідсікача.

До збільшення створюваного розрядження та посилення ефекту гратовідсікання призводить включення в систему відведення продуктів руйнування 7 вакуумної системи 8.

Пристрій для газолазерної різки металевих матеріалів був зібраний на основі газового $\mathrm{CO}_{2}$-лазера потужністю в 1,5 кВт. Фокусування випромінювання здійснювалося лінзою з селеніду цинку з фокусною відстанню $f=127$ мм. В якості робочого газу застосовувався як кисень, так і аргон тиском в 2,0 атм, який витікав 3 сопла з вихідним отвором в 1,0 мм. Система відведення продуктів руйнування складалася з патрубка, сполученого з витяжною системою, гратів для затримання продуктів руйну- 
вання і резервуару для утилізації цих продуктів. Гратовідсікач, виконаний з латуні у вигляді сопла Лаваля протяжністю в 15 мм і з вхідним отвором, рівним 5 мм, кріпився на кінці патрубка системи відведення продуктів руйнування, співісно соплу для подачі робочого газу. Заготовка, що розрізалася, розміщувалася на робочому столі, виконаному 3 гратчастою базовою поверхнею для забезпечення виходу продуктів руйнування з зони різки.

Газолазерній різці піддавалися листи з неіржавіючої сталі і титану завтовшки 2 і 3 мм. При різці неіржавіючої сталі в якості робочого газу застосовувався кисень, а при різанні титану - аргон. Відстань між заготовкою та гратовідсікачем при розрізанні неіржавіючої сталі встановлювалася рівною 3 мм, а при різці титану - 5 мм. При цьому грат на матеріалах різної товщини, що розрізалися, був завжди відсутній. Для порівняння газолазерній різці піддавалися ті ж листи на аналогічних режимах без гратовідсікача. Аналіз отриманих різів показав наявність грату у вигляді шлаку заввишки до 2 мм на неіржавіючих сталях та грату у вигляді застиглого розплаву висотою до 4 мм на титані.

\section{Висновки}

1. В результаті розгляду явища та аналізу умов гратоутворення на кромках різних металевих матеріалів при їх різці лазерним випромінюванням у присутності струменя піддуваємого робочого газу намічені можливі шляхи боротьби з цим явищем, яке значно знижує якість кромок отримуваних різів при газолазерній різці металів.

2. На основі аналізу можливих варіантів технологічних удосконалень газолазерної різки металевих матеріалів запропонований оригінальний пристрій такої обробки з високою якістю отримуваних різів в результаті усунення гратоутворення на кромках металів, що розрізаються, безпосередньо в процесі різки.

3. Описаний розроблений i впроваджений варіант пристрою для газолазерної різки металевих матеріалів 3 неіржавіючої сталі і титану різної товщини без наявності грату на кромках отримуваних різів та із заданою високою їх якістю.

1. Коваленко В. С. Малоотходные процессы резки лучом лазера / В. С. Коваленко, В. В. Романенко, Л. М. Олещук. - Киев : Техника, 1987. 112 с. 2. Патент Японии № 45-67648 B26f 1/30, 1975 г. 3. Патент Японии № 50-38840 B26f 1/30, 1975 г. 4. А. с. СCСР № 1466137 B23k 26/00, 1988 г.

1. Kovalenko V. S. Maloothodnye processy rezki luchom lazera / V. S. Kovalenko, V. V. Romanenko, L. M. Oleshhuk. - Kiev : Tehnika, 1987. 112 s. 2. Patent Japonii № 45-67648 V26f 1/30, 1975 g. 3. Patent Japonii № 50-38840 V26f 1/30, 1975 g. 4. A. s. SSSR № 1466137 V23k 26/00, $1988 \mathrm{~g}$. 